\title{
Development of a real-time loop-mediated isothermal amplification assay for detection of porcine circovirus 3
}

\author{
Huanan Wang ${ }^{1,5+}$, Xiangnan Liư ${ }^{2,3+}$, Fanwen Zeng ${ }^{2,3 \dagger}$, Tongyuan Zhang ${ }^{4}$, Yuexiao Liann ${ }^{2,3}$, Miaoli Wu², Li Xiao ${ }^{2}$, \\ Yujun Zhu ${ }^{2}$, Yu Zhang ${ }^{2}$, Meili Chen², Ren Huang ${ }^{2}$, Manlin Luo ${ }^{3^{*}}$, Feng Cong ${ }^{2^{*}}$ and Pengju Guo ${ }^{2^{*}}$ (D)
}

\begin{abstract}
Background: Porcine circovirus type 3 (PCV3) is an emerging circovirus species, that has been reported in major pig-raising countries including the United States, China, South Korea, Brazil, Spain, and Poland.

Results: A real-time loop-mediated isothermal amplification (LAMP) assay was developed for rapid detection of porcine circovirus 3 (PCV3). The method had a detection limit of $1 \times 10^{1}$ copies/ $\mu \mathrm{L}$ with no cross-reactions with classical swine fever virus (CSFV) C strain, foot-and-mouth disease virus (FMDV), porcine circovirus 2 (PCV2) LG vaccine strain, porcine epidemic diarrhoea virus (PEDV), porcine respiratory and reproductive syndrome virus (PRRSV), or pseudorabies virus (PRV). The PCV3 positive detection rate of 203 clinical samples for the real-time LAMP assay was $89.66 \%(182 / 203)$.
\end{abstract}

Conclusions: The real-time LAMP assay is highly sensitive, and specific for use in epidemiological investigations of PCV3.

Keywords: Porcine circovirus 3, Real-time LAMP, Epidemiological investigations

\section{Background}

In June 2015, an outbreak of porcine dermatitis and nephropathy syndrome (PDNS) was reported in a commercial pig farm in North Carolina, United States. Compared with the historical data, the mortality rate of sows increased by $10.2 \%$ and the pregnancy rate dropped $0.6 \%$. The affected sows were anorexic and their skin presented multifocal papules, plaques and superficial dermatitis. The manifestation of infected foetuses included weak, stillborn and mummified individuals. A new virus was isolated from these animals with the help of next-generation sequencing technology and was identified as porcine circovirus 3 (PCV3) [1]. PCV3 was

\footnotetext{
*Correspondence: 710510116@qq.com; congfeng521@126.com; vetbio2016@hotmail.com

${ }^{\dagger}$ Huanan Wang, Xiangnan Liu and Fanwen Zeng contributed equally to this work.

${ }^{3}$ Guangdong Provincial Key Laboratory of Zoonosis Prevention and Control, College of Veterinary Medicine, South China Agricultural University, Guangzhou 510640, China

${ }^{2}$ Guangdong laboratory animals monitoring institute and Guangdong Provincial Key Laboratory of Laboratory Animals, Guangzhou 510633, China Full list of author information is available at the end of the article
}

subsequently widely detected in China, Korea, Brail and many other European countries including Poland, Italy, Spain, Denmark, Germany, and the United Kingdom [2-6].

Porcine circovirus 3 (PCV3) is a member of the Circovirus genus in the Circoviridae family. The clinical symptoms and pathological changes of PCV3-infected pigs were highly similar to those of PCV2-infected pigs [7]. Given that the virus may be highly prevalent globally, an accurate laboratory diagnosic for rapid confirmation of PCV3 infection is needed. Recently, conventional loop-mediated isothermal amplification (LAMP) assays and PCR-based diagnostic assays for PCV3 have been developed [8-10]. Real-time LAMP is a constant temperature amplification method carried out at $60-65^{\circ} \mathrm{C}$, for which only a simple water bath is required. Real-time LAMP eliminates reverse transcription steps as well as PCR instrument cooling time, which shortens the amplification time. Adding a fluorescent DNA intercalating dye into the real-time LAMP reaction enables monitoring of a fluorescence amplification curve [11]. Compared to conventional LAMP assays, this 
method avoids visible error, enables quantitative detection and is more suitable for multi-sample analysis. Because of its simple reaction conditions and ease of use, the realtime LAMP method has been adapted for the detection and diagnosis of a variety of pathogens $[12,13]$. In this study, a real time RT-LAMP assay was developed for the rapid diagnosic of PCV3.

\section{Results}

Sensitivity and specificity of the real-time LAMP assay for rapid detection of $\mathrm{PCV} 3$

Ten-fold serial dilutions of plasmid DNA were used as templates in the assay. The detection limit of the assay was $1 \times 10^{1}$ copies/ $\mu \mathrm{L}$ per reaction (Fig. 1 ). These results indicated the real-time LAMP assay could be used as a sensitive diagnostic test for PCV3.

The specificity of the reactions was identified using DNA templates of PCV2, PCV3, PRV and other swine viral cDNA samples including those of CSFV, FMDV, PEDV, and PRRSV. The experiment was performed in duplicate. All reactions containing PCV3 were positive in the real-time LAMP assay. The other viral samples mentioned above were negative, indicating that the assay was highly specific for PCV3 (Fig. 2).

\section{Clinical sample testing}

The real-time LAMP were performed to test for PCV3 DNA in 203 clinical samples as previously described [10]. The PCV3-positive rate detected by the real-time LAMP was $89.66 \%(182 / 203)$ (Table 1$)$.

\section{Discussion}

In this study, a novel real-time LAMP assay for detecting PCV3 was developed, and 203 clinical samples were used to validate the field application of the assay. This assay introduces a new method for the laboratory detection of PCV3 that does not rely on expensive equipment and instrumentation. Thus, the real-time LAMP assay established in this study is a valuable alternative for the detection of PCV3.

To the best of our knowledge, this method is the first real-time LAMP assay for the PCV3 detection, which has a detection limit of $1 \times 10^{1}$ copies/ $\mu \mathrm{L}$ for PCV3, and is more sensitive than regular PCR. According to previous reports, the limit of detection of PCV3 was $1.73 \times$ $10^{2}$ copies $/ \mu \mathrm{L}$ and $10^{2}$ copies/ $\mu \mathrm{L}$ with a SYBR Green-based real-time quantitative PCR assay and a TaqManbased real-time PCR assay, respectively [9, 10]. In this real-time LAMP study, the detection limit was only approximately $1 \times 10^{1}$ copies $/ \mu \mathrm{L}$. Both real-time LAMP and conventional PCR [1] were performed to demonstrate the presence of PCV3 DNA in samples as previously described [10]. The PCV3-positive rates detected by conventional PCR, real-time quantitative PCR and real-time LAMP were $26.60 \%$ (54/203) [10], 86.70\% $(176 / 203)$ [10], and $89.66 \%$ (182/203), respectively. Furthermore, the samples that were positive for PCV3 by the real-time LAMP assay but negative by the conventional PCR assay were confirmed by the nested PCR (S1) [14]. Positive PCR products were confirmed by sequencing (S2). These results demonstrate that the real-time LAMP assay was sufficient, accurate and reliable as a molecular diagnostic test for the detection of PCV3.

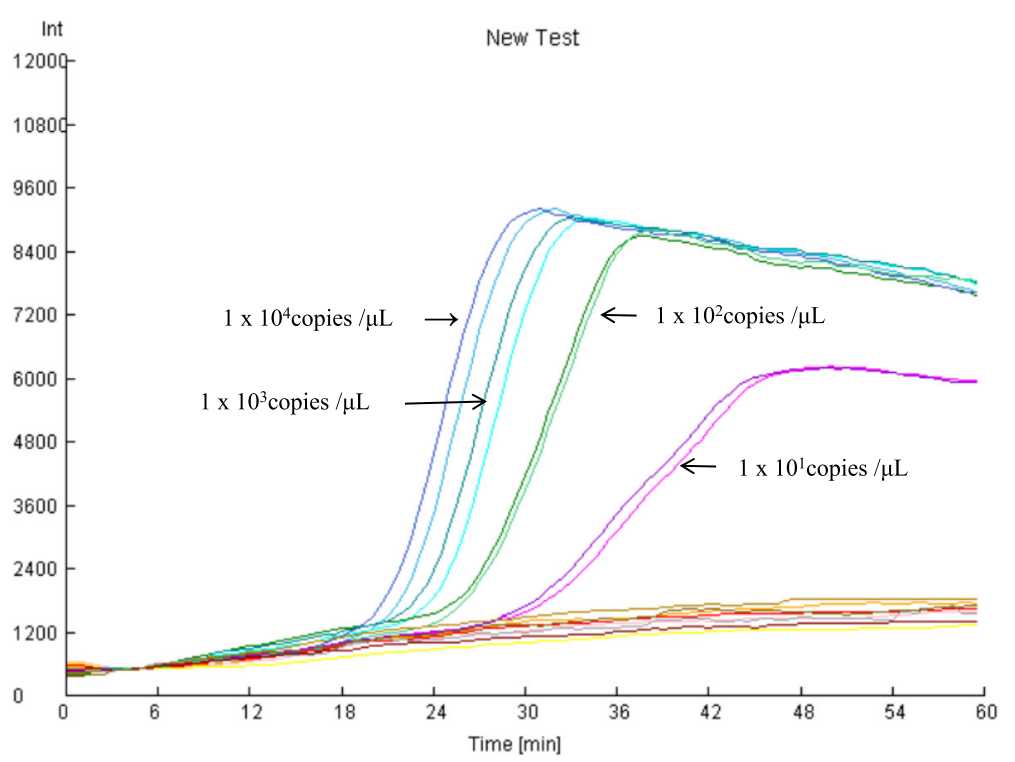

Fig. 1 Sensitivity of the LAMP assay for PCV3. Ten-fold serial dilutions of plasmids containing a cloned fragment of the PCV3 capsid gene were used for the assay. Negative control, $\mathrm{H}_{2} \mathrm{O}$. All reactions were performed in duplicate 


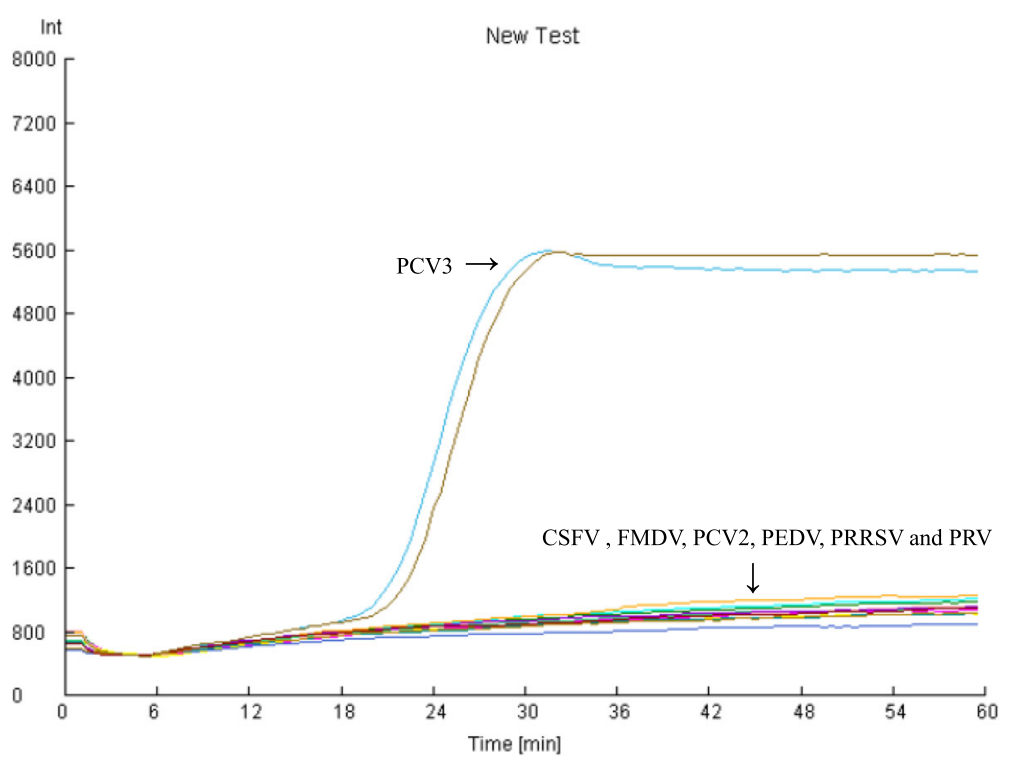

Fig. 2 Specificity of the LAMP assay. DNA from PCV2, PRV and CDNA of other swine viral pathogens including FMDV, PEDV, CSFV and PRRSV was tested in the LAMP assay. $\mathrm{H}_{2} \mathrm{O}$ was used as template for mock samples. All reactions were performed in duplicate

\section{Conclusion}

A novel real-time LAMP assay was developed in this study for the detection of PCV3 nucleic acids. This PCV3 real time LAMP assay was highly specific, sensitive and reliable. This assay will be useful for the diagnosis and epidemiological and pathogenesis studies of PCV3 infections.

\section{Methods}

\section{Virus strains and clinical samples}

Clinical samples including 36 brains, 29 hearts, 34 livers, 31 spleens, 34 lungs, 29 kidneys and 10 sera from pigs from a previous experiment that were stored at Jingyun Ma's lab (South China Agricultural University, Guangzhou, China) were subjected to a real-time LAMP assay [10]. Six porcine viruses were used for specificity testing of PCV3. These viruses were classical swine fever virus (CSFV) $\mathrm{C}$ strain, foot-and-mouth disease virus (FMDV), porcine circovirus 2 (PCV2) LG vaccine strain, porcine epidemic diarrhoea virus (PEDV), porcine respiratory and reproductive syndrome virus (PRRSV), and pseudorabies virus (PRV) $[13,15]$.

Table 1 Screening results for 203 clinical samples for real time LAMP, real-time PCR and conventional PCR assay

\begin{tabular}{|c|c|c|c|c|c|c|c|c|}
\hline \multirow{2}{*}{$\begin{array}{l}\text { Molecular } \\
\text { technique }\end{array}$} & \multicolumn{7}{|c|}{ Samples } & \multirow{2}{*}{$\begin{array}{l}\text { Proportion } \\
\text { positive }\end{array}$} \\
\hline & Brain & Heart & Liver & Spleen & Lung & Kidney & Serum & \\
\hline Real time LAMP & $\begin{array}{l}24 / \\
36\end{array}$ & $\begin{array}{l}26 / \\
29\end{array}$ & $\begin{array}{l}32 / \\
34\end{array}$ & $29 / 31$ & $\begin{array}{l}32 / \\
34\end{array}$ & $29 / 29$ & $10 / 10$ & $\begin{array}{l}89.66 \%(182 / \\
203)\end{array}$ \\
\hline Real-time PCR & $\begin{array}{l}23 / \\
36\end{array}$ & $\begin{array}{l}26 / \\
29\end{array}$ & $\begin{array}{l}29 / \\
34\end{array}$ & $29 / 31$ & $\begin{array}{l}32 / \\
34\end{array}$ & $27 / 29$ & $10 / 10$ & $\begin{array}{l}86.70 \%(176 / \\
203)\end{array}$ \\
\hline $\begin{array}{l}\text { Conventional } \\
\text { PCR }\end{array}$ & $6 / 36$ & $\begin{array}{l}11 / \\
29\end{array}$ & $7 / 34$ & $8 / 31$ & $9 / 34$ & $9 / 29$ & $4 / 10$ & $26.6 \%(54 / 203)$ \\
\hline
\end{tabular}

\section{Nucleic acid extraction}

Frozen field samples were homogenized for $30 \mathrm{~s}$ with a tissue homogenizer in phosphate-buffered saline (PBS) to prepare samples for extraction procedures. Viral DNA and RNA were extracted from the samples using a TGUide Virus DNA/RNA Kit and T-Guide instrument according to the manufacturer's instructions (Tiangen, Beijing, China). The RNA viruses were treated with a PrimeScript $^{\text {tix }}$ RT reagent Kit with gDNA Eraser kit (Takara, China) according to the manufacturer's instructions.

\section{Design of primers for real-time LAMP}

Real-time LAMP primers targeting on the PCV3 cap gene (accession number KY418606.1) were designed using the program http://primerexplorer.jp and were synthesized by Sangon (Sangon Biotech, Shanghai, China). The primers included two inner primers (PCV3FIP and PCV3-BIP) and two outer primers (PCV3 -F3 and PCV3-B3) (Table 2).

\section{Construction of plasmids containing the cap gene of PCV3}

The target fragment was amplified using primers PCV3F3 and PCV3-B3 and cloned into the pMD-18 T vector (Takara, China), which was transformed into Escherichia coli competent cells according to the manufacturer's instructions (DH5 $\alpha$, Tiangen, Beijing, China). The plasmid containing the PCV3 cap gene (pMD-18 T-cap) was purified using a commercial kit (Tiangen, Beijing, China). The concentration of the plasmid sample was determined by measuring the absorbance at $260 \mathrm{~nm}$, 
Table 2 Oligonucleotide primers used in this study

\begin{tabular}{ll}
\hline Name & Sequence((5'-3') and Position \\
\hline PCV3-B3 & GCAGTGCTCCCCATTGAAC (1425-1443) \\
PCV3-F3 & ACACTTGGCTCCAAGACGA (1610-1628) \\
PCV3-BIP & GAACTACCAGCGCTCACCCAG (1503-1520)- \\
& GGTGGGTCATATGTGTGA (1444-1463) \\
PCV3-FIP & TGGGGGTGAAGTAACGGCTGT (1539-1559)- \\
PCV3-LB & TGCGGAAGTCCACTCGTA (1584-1603) \\
\hline
\end{tabular}

using a NanoDrop Lite spectrophotometer (Thermo Scientific, USA), and the copy number of the cloned gene was quantified as follows [16]: [copies $/ \mu \mathrm{L}=$ concentration of plasmid $(\mathrm{g} / \mu \mathrm{L}) /[$ (plasmid length $\times 660) \times(6.022 \times$ $\left.\left.10^{23}\right)\right]$

\section{Development of real-time LAMP assay}

The real-time LAMP reaction mixture contained template DNA or cDNA, inner primers (FIP and BIP) at 1.6 $\mathrm{mM}$, outer primers (F3 and B3) at $0.2 \mathrm{mM}$, loop backward primers (LB) at $0.8 \mathrm{mM}, 1 \mu \mathrm{L}$ of Bst DNA polymerase (M5038 L, New England Biolabs, MA, USA), betaine at $0.8 \mathrm{M}$ (BCBS087V, Sigma St. Louis, MO USA), dNTPs at $1.4 \mathrm{mM}, 2.5 \mu \mathrm{L}$ of amplification buffer (B0537S, New England Biolabs), $8 \mathrm{mM}$ of $\mathrm{MgSO}_{4}$ and SYTO-9 green fluorescent nucleic acid stain at $0.1 \mathrm{mM}$ (S34854, Invitrogen, Carlsbad, CA, USA). Double-distilled water was used as a negative control. The mixture was incubated at $63{ }^{\circ} \mathrm{C}$ for $60 \mathrm{~min}$ and then heated at $80{ }^{\circ} \mathrm{C}$ for $10 \mathrm{~min}$ to terminate the reaction. Finally the results were detected using a Thermostatic Fluorescence Detector (DEAOU-308C, Diao, Guangzhou, China) and are shown by the graph. Specificity of the method was determined using DNA templates of PCV2, PCV3, PRV and other swine viral cDNA samples from CSFV, FMDV, PEDV, and PRRSV. Ten-fold serial dilutions of pMD-18 T-cap were used to calculate the analytical sensitivity. The method was further evaluated using 203 clinical samples [10]. $\mathrm{H}_{2} \mathrm{O}$ was used as template for mock samples. All reactions were performed in duplicate.

\section{Abbreviations \\ CSFV: Classical swine fever virus; FMDV: Foot-and-mouth disease virus; PCV2: Porcine circovirus 2; PCV3: Porcine circovirus type 3; PDNS: Porcine dermatitis and nephropathy syndrome; PEDV: Porcine epidemic diarrhoea virus; PRRSV: Porcine respiratory and reproductive syndrome virus; PRV: Pseudorabies virus}

\section{Acknowledgments}

We are very grateful to Pr. Jingyun Ma (South China Agricultural University, Guangzhou, China) for the clinical samples.

\section{Authors' contributions}

$P G, F C, M L$ and $H W$ designed the study, and wrote the paper; and HW, XL and FZ analyzed the data, and contributed to sample processing, viral DNA or RNA extraction and PCR; TZ, YL, MW, LX, YZ1, and YZ2 helped to finish the research; MC, and $\mathrm{RH}$ provided valuable suggestion and revised the paper. All authors read and approved the final manuscript.

\section{Funding}

The study was supported by Science and Technology Research Program (2018B030317001, 2017A070702001, 2017B030314171, 2015B070701003 and 2016A040403060) from Guangdong Provincial Department of Science and Technology, China. This study was also supported by Science and Technology Research Program (201707010440) and (2016201604030059) from Guangzhou Science Technology and Innovation Commission, China. The funding bodies had no role in the design of the research, the collection, analysis, and interpretation of data, and the writing of the manuscript.

\section{Availability of data and materials}

All data generated or analyzed during the study are included in this published article.

\section{Ethics approval and consent to participate}

In our research, the clinical samples were submitted to Jingyun Ma's lab in South China Agricultural University for routine animal health monitoring. Animal experiment was not used in our research. Thus, Ethics approval and consent to participate are not applicable and animal' owners permit us to do this research.

\section{Consent for publication}

Not applicable.

\section{Competing interests}

The authors declare that they have no competing interests.

\section{Author details}

${ }^{1}$ Department of Veterinary Medicine, Zhejiang Provincial Key Laboratory of Preventive Veterinary Medicine and College of Animal Sciences, Zhejiang University, Hangzhou 310058, China. ${ }^{2}$ Guangdong laboratory animals monitoring institute and Guangdong Provincial Key Laboratory of Laboratory Animals, Guangzhou 510633, China. ${ }^{3}$ Guangdong Provincial Key Laboratory of Zoonosis Prevention and Control, College of Veterinary Medicine, South China Agricultural University, Guangzhou 510640, China. ${ }^{4}$ Center for Animal Disease Control and Prevention, FuShun 113006, China. ${ }^{5}$ Zhejiang Provincial Key Laboratory of Preventive Veterinary Medicine, College of Animal Sciences, Zhejiang University, Hangzhou 310058, China.

Received: 10 January 2019 Accepted: 2 August 2019

Published online: 23 August 2019

\section{References}

1. Palinski R, Pineyro P, Shang PC, Yuan FF, Guo R, Fang Y, Byers E, Hause BM. A novel porcine circovirus distantly related to known circoviruses is associated with porcine dermatitis and nephropathy syndrome and reproductive failure. J Virol. 2017;91. doi: https://doi.org/10.1128/JVI.01 879-16.

2. Ku X, Chen F, Li P, Wang Y, Yu X, Fan S, Qian P, Wu M, He Q. Identification and genetic characterization of porcine circovirus type 3 in China. Transbound Emerg Dis. 2017;64:703-8.

3. Kwon T, Yoo SJ, Park CK, Lyoo YS. Prevalence of novel porcine circovirus 3 in Korean pig populations. Vet Microbiol. 2017;207:178-80.

4. Stadejek T, Wozniak A, Milek D, Biernacka K. First detection of porcine circovirus type 3 on commercial pig farms in Poland. Transbound Emerg Dis. 2017;64:1350-3.

5. Tochetto C, Lima DA, Varela APM, Loiko MR, Paim WP, Scheffer CM, Herpich J, Cerva C, Schmitd C, Cibulski SP, et al. Full-genome sequence of porcine circovirus type 3 recovered from serum of sows with stillbirths in Brazil. Transbound Emerg Dis. 2018;65:5-9.

6. Li GR, He WT, Zhu HA, Bi YH, Wang RY, Xing G, Zhang C, Zhou JY, Yuen KY, Gao GF, Su S. Origin, genetic diversity, and evolutionary dynamics of novel porcine circovirus 3. Adv Sci. 2018;5:1800275.

7. Zhai SL, Zhou X, Zhang H, Hause BM, Lin T, Liu R, Chen QL, Wei WK, Lv DH, Wen $\mathrm{XH}$, et al. Comparative epidemiology of porcine circovirus type 3 in pigs with different clinical presentations. Virol J. 2017;14:222. 
8. Kim HR, Park YR, Lim DR, Park MJ, Park JY, Kim SH, Lee KK, Lyoo YS, Park CK. Multiplex real-time polymerase chain reaction for the differential detection of porcine circovirus 2 and 3. J Virol Methods. 2017;250:11-6.

9. Wang J, Zhang Y, Wang J, Liu L, Pang X, Yuan W. Development of a TaqMan-based real-time PCR assay for the specific detection of porcine circovirus 3. J Virol Methods. 2017;248:177-80.

10. Chen GH, Tang XY, Sun Y, Zhou L, Li D, Bai Y, Mai KJ, Li YY, Wu QW, Ma JY. Development of a SYBR green-based real-time quantitative PCR assay to detect PCV3 in pigs. J Virol Methods. 2018;251:129-32.

11. Oscorbin IP, Belousova EA, Zakabunin Al, Boyarskikh UA, Filipenko ML. Comparison of fluorescent intercalating dyes for quantitative loop-mediated isothermal amplification (qLAMP). Biotechniques. 2016;61:20-5.

12. Yu X, Shi L, Lv X, Yao W, Cao M, Yu H, Wang X, Zheng S. Development of a real-time reverse transcription loop-mediated isothermal amplification method for the rapid detection of porcine epidemic diarrhea virus. Virol J. 2015;12:76.

13. Wang H, Cong F, Zeng F, Lian Y, Liu X, Luo M, Guo P, Ma J. Development of a real time reverse transcription loop-mediated isothermal amplification method (RT-LAMP) for detection of a novel swine acute diarrhea syndrome coronavirus (SADS-CoV). J Virol Methods. 2018;260:45-8.

14. Yongning Y, Yijia R, Luchang S. Establishment and application of nested PCR for detection of porcine circovirus type 3. Heilongjiang Anim Sci Vet Med. 2019;02:60-2 65.

15. Zeng F, Cong F, Liu X, Lian Y, Wu M, Xiao L, Yuan W, Huang R, Ma J, Guo P, Luo M. Development of a real time loop-mediated isothermal amplification method for detection of Senecavirus a. J Virol Methods. 2018:261:98-103.

16. Parida M, Shukla J, Sharma S, Ranghia Santhosh S, Ravi V, Mani R, Thomas M, Khare S, Rai A, Kant Ratho R, et al. Development and evaluation of reverse transcription loop-mediated isothermal amplification assay for rapid and real-time detection of the swine-origin influenza a H1N1 virus. J Mol Diagn. 2011;13:100-7.

\section{Publisher's Note}

Springer Nature remains neutral with regard to jurisdictional claims in published maps and institutional affiliations.

Ready to submit your research? Choose BMC and benefit from:

- fast, convenient online submission

- thorough peer review by experienced researchers in your field

- rapid publication on acceptance

- support for research data, including large and complex data types

- gold Open Access which fosters wider collaboration and increased citations

- maximum visibility for your research: over $100 \mathrm{M}$ website views per year

At $\mathrm{BMC}$, research is always in progress.

Learn more biomedcentral.com/submissions 